\title{
Save the planet
}

\section{Amarasekera $\mathrm{N}$}

Journal of the Ceylon College of Physicians, 2016, 47, 55

Global warming leading to climate change From drought to floods, a catastrophic range! The world at last seems to have realized All are culpable, should all be penalized?

Developed countries powered their Way to prosperity Using fossil fuels, its impact then unknown to humanity When developing countries, the ladder to climb now seek The developed ones protest! The height of cheek!

The developed exceed environmental limits through greed

Call to limit green house gases giving the lead The deprived are struggling to meet their needs bare From those steeped in poverty is the request fair?

$500 / 0$ of carbon emissions are caused by $100 / 0$ of the richest While $1.00 / 0$ is produced by $500 / 0$ of the poorest When such are the figures only the meanest I dare say Would at the door of the poorest the blame lay

Technology is available but is it accessible or affordable To harness wind, water and the sun costs are formidable To shift the burden on the poor is it morally acceptable! Living in clover the rich do not give up even the dispensable!

Government heads and world leaders have come to their senses Organized a meeting in Paris, termed "Climate Rescue Summit" There is only this one world, there is no planet B! The leaders addressed the subject for the world to see

In support of the "Save the Planet" movement All came together at this important moment Fate of humanity is at stake, let's get together As Mother Earth has reached the end of the tether

From Hollywood heavyweights to Asia's slums Humans formed chains answering to beating drums Standing on the bed rock of collective enterprise The nations made a decision taking all by surprise

If without pride and prejudice prevails sanity There is hope - do not despair for humanity If global warming can be sensibly curtailed The world's climate a century ago can be regained

\footnotetext{
${ }^{1}$ Consultant Physician, Colombo, Sri Lanka.
}

E-mail: nanda_amar@live.com 